\section{A TRICHINOSIS OUTBREAK CAUSED BY WILD BOAR MEAT IN TURKEY}

HEPER Y.*, YILMAZTEPE F.**, KOMITOVA R.***, AKALIN H.*, VUTOVA K.**** \& HELVACI S.*

Sir,

The main route of human trichinosis is eating raw or undercooked pork, but there are also reports of some cases and outbreaks caused by wild boar, horse, dog, cougar, walrus, badger meat, etc., in the literature. Trichinosis is extremely rare in Turkey, because eating pork is prohibited in Islam and consumption of wild game meat is uncommon. Not to be considered in differential diagnosis may cause delays in the diagnosis and the treatment. Here we present an index case and a number of related cases which could only be diagnosed after the patient's friends had similar complaints and explained that they had eaten wild boar meat all together.

\section{CASE REPORT}

In February 2003, a 35-year old male was hospitalized in our Infectious Diseases Clinic with abdominal pain, fever, diarrhoea, dark urine, edema on eyelids and rashes on legs and forearms which had begun three to four weeks ago. During these three weeks he was misdiagnosed with allergy, dysenteria, salmonellosis, non specific infection and was referred to our clinic because no recovery was achieved through medications. During his stay in our clinic, we were informed that six friends of him had similar complaints and after a careful questioning it was discovered that they all had eaten wild boar meat approximately 40 days ago, which they had hunted four days before consumption. In six of them the complaints had begun three-four weeks and in one case one week before. The major symptoms were weakness in four, fever in all, myalgia in six, diarrhoea in five, edema on eyelids and face, and cutaneous rashes in six of the total seven cases. Leucocyte count was 21,200/ $\mathrm{mm}^{3}$ (eosiniphils \% 35), CPK $1334 \mathrm{U} / \mathrm{L}$ (normal: 12-200 U/L), and LDH 862 U/L (normal: 190-

\footnotetext{
* Uludag University School of Medicine, Department for Microbiology and Infectious Diseases, Bursa, Turkey.

*** Hurriyet Private Medical Center, Bursa, Turkey.

**** Medical University, Department of Infectious, Parasitic, Tropical Diseases, Sofia, Bulgaria.

Correspondence: Dr Yasemin Heper, Uludag Universitesi Tip Fakultesi, Enfeksiyon Hastalıkları ve Mikrobiyoloji Anabilim Dali, 16059 Gorukle, Bursa, Turkey.

Tel. + Fax: 00902244428331 .

E-mail: yheper@superonline.com
}

$380 \mathrm{U} / \mathrm{L}$ ) in the index case. Eosinophilia was found in all of the cases, ranging from 18 to $35 \%$. Leucocytosis and elevated transaminase levels were present in six of the seven cases. Muscle biopsy performed in one case showed myositis, but no Trichinella larvae were seen. As a result of suspected trichinosis, albendazole $(2 \times 400 \mathrm{mg}$ for 14 days) was given to the index case, and mebendazole $(3 \times 200 \mathrm{mg}$ for seven days $)$ to the other six cases in an outpatient clinic. At the end of the treatment, complaints in all of the cases disappeared.

Frozen serum samples (at $-20^{\circ} \mathrm{C}$ ) from all cases were sent to The Sofia Laboratory of Parasitology, Department of Infectious, Parasitic and Tropical Diseases, and tested there for anti-trichinosis antibodies (BulBioNCIPD Ltd, Bulgarian test). Agglutination tests were found positive in all of the cases (1/200 in three, $1 / 1,600$ in two and 1/3,200 in two cases), but IFA tests were positive in only four of them. The IFA test missed one case which was positive at 1/3,200 and two at $1 / 200$ in the agglutination tests.

\section{DisCUSSION}

Symptoms of trichinosis may cause confusion, but eosinophilia is important, elevated levels of CPK, LDH, AST and ALT may be admonitory. A muscle biopsy and/or detection of antibodies may confirm the diagnosis, but a biopsy is not mandatory. Antibodies are detectable two-three weeks after the infection, may be measured by enzyme-immune assay, immunofluorescent, indirect hemagglutination, precipitin and bentonit flocculation assays, and a western-blott kit is under development (Capo, 1996; Grove, 2000; Yera et al., 2003).

Trichinosis is very rare in Turkey. There is only one data, an index case and two related cases from Istanbul reported by Merdivenci, that was traced to a wild boar hunted in Kastamonu, Northern Anatolia, in 1977. In the same paper, it is noted that 13 other people were affected as well (Merdivenci et al., 1977). In January 2004, one year after our cases, a large outbreak occured in Izmir, Western Anatolia, that affected hundreds of people (not published yet), which has been traced to a single restaurant and butcher (www.promedmail.org). Trichinellosis prevalence among animals is also not well known in Turkey. There are only two publications. The parasite was found in one of 70 wild boars hunted in Polatli, Ankara, in Central Anatolia, but in none of six which were shot in the Taurus montains, in Southern Anatolia (Rommel, 1971). Between 1979-1983 Nazli examined 535 pigs, 1,165 wild 
boars and 600 pork products ( 125 sausages, 150 salamis, 200 smoked ham, 50 pieces raw pork) and found Trichinella spiralis in two of the 1,165 wild boars ( $0.17 \%)$, but in none of the pigs or pork products. The two infected wild boars were hunted in Kastamonu, Northern Anatolia, as in the cases of Merdivenci (Nazli, 1987). The wild boar of our cases was shot in Karacabey, Northwestern Anatolia, in the southern Marmara region.

\section{CONCLUSION}

Trichinosis should be kept in mind, because consumption of wild game meat individually or via uncontrolled and illegal marketing can always be a route for the disease, and must be examined in suspected patients, especially in patients with eosinophilia.

\section{REFERENCES}

Capo V. \& Despommier D.D. Clinical aspects of infection with Trichinella spp. Clinical Microbiology Rewiews, 1996, 9, 47-54.

Grove D.I. Tissue nematodes (Trichinosis, Dracunculiasis filariasis), in: Principles and practice of infectious diseases. Mandell G.L., Bennet J.E. \& Dolin R. (eds), $5^{\text {th }}$ edition. Churchill Livingston, Philadelphia, 2000, 2943-2950.

Merdivenci A., Aleksanyan V., Girisken G. \& Perk M. Türkiye'de insanda ilk Trichinella spiralis infeksiyonu olgusu (The first human case of Trichinella spiralis in Turkey). Türk Mikrobiyoloji Cemiyeti Dergisi, 1977, 7, 65-88.

NAZLI B. \& INAL T. Untersuchungen über das Vorkommen von Trichinella spiralis bei Haus und Wildschwein sowie aus diesen hergestellten Produkten in der Türkei (Research for Trichinella spiralis in pigs, wild boars and pork products in Turkey). Berl. Münch. Tieraerztl. Wschr. 1987, 100, 187190.

Rommel M. Trichinose beim Schwarzwild in der Provinz Ankara (Trichinosis in wild boar in Ankara). J. Fac. Vet. Med. Univ. Ankara, 1971, 18, 219-221.

Yera H., Andiva S., Perret C., Limonne D., Boireau P. \& Dupouy-CAMET J. Development and evaluation of a Western blot kit for diagnosis of human Trichinellosis. Clinical and Diagnostic Laboratory Immunology, 2003, 10, 793-796. 